\title{
Consistent magnitude of postpartum body weight loss within cows across lactations and the relation to reproductive performance
}

\author{
M. Zachut ${ }^{1}$ and U. Moallem \\ Department of Ruminant Science, Institute of Animal Sciences, Volcani Center, PO Box 15159, Rishon LeZion 7528809, Israel
}

\begin{abstract}
Great variation exists among cows in the magnitude of tissue mobilization during early lactation; however, it is not known whether this is an intrinsic trait. Our aims were (1) to test whether the degree of body weight (BW) loss is consistent within cows across lactations by examining daily BW records of 4 to 5 consecutive lactations and their relation to milk yield, health disorders, and reproductive performance; and (2) to examine, in an intensive study, the possible underlying physiological mechanism. Data from 416 first to fifth consecutive lactations obtained from 92 Israeli highyielding Holstein dairy cows were analyzed. Cows were divided according to percentage of BW loss from wk 1 to 5 postpartum in their last lactation, into groups of (1) low weight loss (LWL; -3 to $6 \%$; $\mathrm{n}=37$ ) and (2) high weight loss (HWL; 7 to $17 \%$; $\mathrm{n}=55$ ). The average percentage of BW loss was $7.6 \%$ in the HWL group and $5.3 \%$ in the LWL group, and the pattern was consistent between groups across lactations. Milk and $4 \%$ fat-corrected milk yields during the first $30 \mathrm{~d}$ in milk across lactations were higher in HWL than in LWL groups, but 305-d yields were similar. The number of open days and the interval between lactations were consistent across lactations, 17 and $20 \mathrm{~d}$ longer, respectively, in HWL versus LWL cows. Across lactations, the conception rates from first, second, and third artificial inseminations were $9.6 \%$ higher in LWL than in HWL cows. No differences in the incidence of health disorders were observed between groups. The intensive study was conducted with 12 randomly selected peripartum cows divided into c-HWL and c-LWL groups according to the same criteria. Similar dry matter intake and efficiency calculations were observed between groups postpartum, implying that the differences may not be related to these factors. In response to a glucosetolerance test, c-HWL cows had higher insulin secretion
\end{abstract}

Received July 18, 2016.

Accepted November 21, 2016.

${ }^{1}$ Corresponding author: mayak@volcani.agri.gov.il pre- and postpartum than c-LWL cows, suggesting the former had lower sensitivity to insulin. This is the first study demonstrating that the magnitude of BW loss postpartum within cows is consistent across lactations, and this trait is associated with reproductive performance. The degree of BW loss postpartum, regardless of genetic merit for milk production, seems to be an intrinsic trait that represents the variation in trade-off toward tissue mobilization between cows.

Key words: body weight, consistent pattern, reproduction, dairy cow, insulin sensitivity

\section{INTRODUCTION}

The transition from late gestation to lactation involves a great metabolic challenge: shifting from a nonlactating lipogenic period to a state of tremendous energy demand for milk production. That energy demand results in mobilization of adipose and muscle tissues, as the cow is not able to consume sufficient nutrients to meet the energy requirements of the mammary gland (Bell and Bauman, 1997), and also appears to have a genetic basis (Friggens et al., 2007). The transition period is also characterized by immune dysfunction (Mallard et al., 1998), negative energy balance (Goff and Horst, 1997; Drackley, 1999), and increased incidence of health and metabolic disorders (Goff and Horst, 1997; Mallard et al., 1998). In addition, the negative energy balance in early lactation has adverse effects on cow fertility (Butler and Smith, 1989).

Great variation exists among cows in tissue mobilization during early lactation, and dairy cows in the same herd and consuming the same diet show great variation in feed intake, milk yield, BW gain, and energy balance (McNamara, 2012). The variation in metabolic pathways in adipose tissue, muscle, and liver is striking; within a herd of similar cows on the same diet, use of energy for metabolic functions can vary by $100 \%$ among animals (Onken et al., 2011; McNamara, 2012). However, significant unresolved variation in metabolism remains that defines the summative energy efficiencies (McNamara, 2012). 
Variations in fat mobilization in high-yielding dairy cows during early lactation differentially affects lipid and glucose metabolism (Weber et al., 2013). We previously reported differential responses to metabolic stress during the transition period, as insulin signaling in adipose tissue was altered in a subgroup of cows that lost more BW postpartum and a correlation between BW loss and insulin responsiveness in adipose tissue was also observed (Zachut et al., 2013). Our recent finding of differential biomarker protein abundances in adipose tissues of peripartum dairy cows, which are related to individual responses to metabolic stress (Zachut, 2015), is further evidence of cow-to-cow variability.

The interspecies variation and repeatability of the response to metabolic stress was recently investigated in dairy cows (Gross and Bruckmaier, 2015) and goats (Friggens et al., 2016); however, in those studies, the response was tested in the same lactation. Automatically generated BW records, which are objective and quantitative (as compared with BCS), are now available in many farms over lactations. A consistent pattern of BW loss in 8 cows across lactations was found in our previous study (Zachut et al., 2013). Therefore, the aims of the present work were (1) to test the hypothesis that the magnitude of BW loss is an intrinsic trait in animals by using a data set of automatically generated daily BW measurements across lactations and examining their relation to milk production, health disorders, and reproductive performance; and (2) to examine, in an intensive study, the possible physiological mechanism underlying the variation between animals in the degree of BW loss postpartum.

\section{MATERIALS AND METHODS}

\section{Cows and Data Collection}

Data were collected from the dairy farm at the Volcani Center (Rishon LeZion, Israel), which has automatically generated daily records of milk yield and BW data for the last $15 \mathrm{yr}$. Thus, a data set of consecutive lactations of adult cows in the herd could be analyzed. For the current analysis, we randomly selected 92 Israeli Holstein cows that had had at least 4 full lactations in recent years. We excluded all data from $>5$ lactations due to the low number of cows with this many lactations.

All cows were milked 3 times a day, yields were recorded electronically by the Afimilk system (SAE Afikim, Kibbutz Afikim, Israel), and milk solids (protein, fat, and lactose contents) were determined once a month according to International Dairy Federation Standard 141C (International Dairy Federation, 2000) by infrared analysis at the Israeli Cattle Breeders Association (Caesarea, Israel) laboratories.

Body weight was measured electronically by a walking scale in the milking parlor (SAE Afikim) 3 times a day, and average daily BW was calculated automatically and recorded. In general, cows were fed a typical Israeli dairy cow ration that contained, per kilogram of $\mathrm{DM}, 1.78 \mathrm{Mcal}$ of $\mathrm{NE}_{\mathrm{L}}, 16.5$ to $16.8 \% \mathrm{CP}$, and 30 to $33 \% \mathrm{NDF}$. The $\mathrm{NE}_{\mathrm{L}}$ values for feedstuffs in rations were determined according to NRC (1989). The concentrateto-forage ratio in diets was 64 to $67 \%$ concentrate and 33 to $36 \%$ forage. The main forage were wheat and corn silages and the overall diet composition was changed from year to year depending on feedstuff availability.

\section{Calculations of BW Loss}

The average BW during the first and fifth week of each cow for every lactation was calculated, and the percentage of BW change from wk 1 to 5 was calculated. Use of these time points was based on our previous work that showed a consistent pattern of BW loss in wk 1 to 5 across lactations in 8 cows (Zachut et al., 2013). As our objective was to determine whether a consistent pattern of BW loss exists in early lactation, cows were divided into 2 groups according to the magnitude of the BW loss in their last lactation; this value was used to calculate the average percentage $\mathrm{BW}$ loss among all cows $(7 \%)$. Cows losing more than the average BW loss were regarded as high weight loss $(\mathbf{H W L}$; range 7 to $17 \% ; \mathrm{n}=55$ ), whereas cows losing less than the average were considered low weight loss (LWL; range -3 to $6 \% ; \mathrm{n}=37)$. This definition was valid for each cow across all lactations. The predicted transmitting ability values of these cows was collected and found not different between groups, at 212.8 and $198.7 \mathrm{~kg}$ for the HWL and LWL groups, respectively $(\mathrm{SEM}=40.1 ; P=0.8)$.

\section{Reproductive and Health Data}

Cows were routinely examined by a veterinarian 7 to $10 \mathrm{~d}$ after calving, treated according to the farm's routine management, and clinical events and treatments were recorded. The BCS of cows (scale 1-5; Edmonson et al., 1989) was also determined by the veterinarian at this visit. All data on postpartum health disorders and reproductive performance (inseminations, date of conception) were taken from the dairy farm database (NOA, Israeli Cattle Breeders Association). Open days, interval between calvings, number of AI per conception, conception rates (CR) at first, second, and third AI, as well as health disorders (ketosis, retained placenta, metritis, and milk fever) were calculated individually for 
each lactation, and then analyzed according to groups (HWL and LWL).

\section{Metabolic Characterization of HWL and LWL Cows}

To further investigate the physiological adaptation of HWL versus LWL cows during the transition period, we conducted an accompanying trial with 12 randomly selected cows from the Volcani farm. Dry pregnant Israeli Holstein cows at $256 \mathrm{~d}$ of pregnancy with average $\mathrm{BW}$ of $663 \pm 76 \mathrm{~kg}$ (mean $\pm \mathrm{SD}$ ) and average lactation number of $2.7 \pm 0.9$ participated in this study from January to March 2015. The Volcani Center Animal Care Committee approved all of the procedures involving animals. Cows were group-housed in shaded outdoor pens with adjacent outside yards, which were equipped with a real-time electronic individual feeding system. Each station was equipped with an individual identification system (SAE Afikim) that allowed each cow to enter a specific station and automatically recorded each meal. Cows were individually fed a TMR once a day at $1100 \mathrm{~h}$ in amounts that ensured $7 \%$ refusals. Cows were fed ad libitum with standard Israeli dry and milking cow rations. The pre- and postpartum diets contained 13.2 and $16.6 \% \mathrm{CP}$ and 1.46 and 1.77 Mcal of $\mathrm{NE}_{\mathrm{L}} /$ $\mathrm{kg}$ of DM, respectively. Amounts of feed offered and refused were recorded daily, and individual intake was calculated throughout the entire study.

Postpartum cows were milked and automatically weighed 3 times daily as mentioned above. Body condition score, on a scale of 1 to 5 , was determined weekly from d 256 of pregnancy through 60 DIM by a single technician. Contents of milk fat, protein, and lactose were determined once a month as mentioned above. Energy content in milk and energy balance were calculated according to (NRC, 2001) as detailed in Zachut et al. (2013). Blood samples were collected 3 times a week from $256 \mathrm{~d}$ of pregnancy until 21 DIM at 0800 $\mathrm{h}$ on Sunday, Tuesday, and Thursday. Samples were collected from the jugular vein into vacuum tubes containing lithium heparin (Becton Dickinson Systems, Cowley, UK), and remained on ice until plasma was harvested. Plasma was collected after centrifugation at $1,500 \times g$ for $20 \mathrm{~min}$ at $4^{\circ} \mathrm{C}$, and stored at $-31^{\circ} \mathrm{C}$ pending analysis. Cows were examined and treated for postpartum diseases as described above.

\section{Glucose Tolerance Test}

At $14 \mathrm{~d}$ before expected calving and $10 \mathrm{~d}$ postcalving, the cows were subjected to a glucose tolerance test (GTT) as described previously (Zachut et al., 2013). Briefly, glucose was administered intravenously as a
$50 \%$ solution (Teva Medical, Ashdod, Israel) with 300 $\mathrm{mg}$ of D-glucose $/ \mathrm{kg}$ of BW at a constant rate by manually compressing the glucose pack. Blood samples were collected $15 \mathrm{~min}$ before the start of the infusion, just before the infusion $(\mathrm{t}=0)$, every $5 \mathrm{~min}$ from $\mathrm{t}=5$ to $\mathrm{t}$ $=45 \mathrm{~min}$, and then at 60 and $75 \mathrm{~min}$. Glucose and insulin concentrations were determined in blood samples.

\section{Chemical Analysis}

Concentrations of plasma insulin were determined by RIA (MP Biomedicals, Solon, OH). The intra- and interassay CV for the insulin assay were 7.2 and $5.1 \%$, respectively. Plasma glucose was determined with a glucose reagent kit (Glucose UV, $10 \times 50 \mathrm{~mL}$; Raichem, San Diego, CA). Plasma fatty acid concentrations were determined with a Wako NEFA C Test Kit (Wako Chemicals GmbH, Neuss, Germany). Plasma malondialdehyde (MDA) concentrations were measured according to the fluorometric thiobarbituric acid reactive substances assay (Feldman, 2004).

\section{Calculations and Statistical Analysis}

In the large set of cows, the percentage of BW change from wk 1 to 5 and BCS at calving for all lactations was analyzed as repeated measurements using the MIXED Procedure of SAS (v. 9.2; SAS Institute Inc., Cary, NC). The model included the effect of group, cows, and lactation number. The final model used was

$$
\mathrm{Y}_{\mathrm{ijkl}}=\mu+\mathrm{G}_{\mathrm{i}}+\mathrm{L}_{\mathrm{j}}+\mathrm{C}(\mathrm{G} \times \mathrm{L})_{\mathrm{ijk}}+\mathrm{E}_{\mathrm{ijkl}},
$$

where $\mathrm{Y}_{\mathrm{ijk}}=$ dependent variable, $\mu=$ overall mean, $\mathrm{G}_{\mathrm{i}}$ $=$ group effect with $\mathrm{i}=1$ to $2(\mathrm{HWL}$ or $\mathrm{LWL}), \mathrm{L}_{\mathrm{j}}=$ lactation with $\mathrm{j}=1$ to $5, \mathrm{C}(\mathrm{G} \times \mathrm{L})_{\mathrm{ijk}}=$ cow $_{\mathrm{k}}$ nested in group $_{\mathrm{i}}$ and lactation ${ }_{\mathrm{j}}$, and $\mathrm{E}_{\mathrm{ijk}}=$ random residual.

Continuous variables, such as milk yield and milk solids, were analyzed as repeated measurements using the MIXED Procedure of SAS:

$$
\mathrm{Y}_{\mathrm{ijklm}}=\mu+\mathrm{G}_{\mathrm{i}}+\mathrm{L}_{\mathrm{j}}+\mathrm{C}(\mathrm{G} \times \mathrm{L})_{\mathrm{ijk}}+\mathrm{DIM}_{\mathrm{ijkl}}+\mathrm{E}_{\mathrm{ijklm}},
$$

where $Y_{\mathrm{ijklm}}=$ dependent variable, $\mu=$ overall mean, $\mathrm{G}_{\mathrm{i}}=$ group effect with $\mathrm{i}=1$ to 2 (HWL or LWL), $\mathrm{L}_{\mathrm{j}}$ $=$ lactation number with $\mathrm{j}=1$ to $5, \mathrm{C}(\mathrm{G} \times \mathrm{L})_{\mathrm{ijk}}=$ $\mathrm{cow}_{\mathrm{k}}$ nested in group $\mathrm{i}_{\mathrm{i}}$ and lactation ${ }_{\mathrm{j}}, \mathrm{DIM}_{\mathrm{ijkl}}=\mathrm{DIM}$ as the continuous variable, and $E_{\mathrm{ijklm}}=$ random residual. Days open and the intervals between calvings were also analyzed with this model, except that the effect of DIM was not included.

The distributions of health disorders and CR were calculated for all lactations and for every lactation sep- 
arately, and analyzed with the GLIMMIX procedure of SAS. Lactation number was used as a blocking factor in the model. The final model contained the fixed effects of group and lactation number, but lactation number was not significant for any one of the tests and was removed from the model. The PROC REG procedure of SAS was used for correlation analysis.

In the smaller trial, continuous variables (milk production, DMI pre- and postpartum, plasma glucose, fatty acids, MDA, and insulin concentration) were analyzed as repeated measurements using the MIXED Procedure of SAS. Subgroup was analyzed as a fixed effect, whereas cow was analyzed as a random effect in the statistical model. The model used was

$$
\begin{gathered}
\mathrm{Y}_{\mathrm{ijklm}}=\mu+\mathrm{G}_{\mathrm{i}}+\mathrm{C}(\mathrm{G})_{\mathrm{ij}}+\mathrm{DIM}_{\mathrm{ijk}} \\
+\mathrm{DIM}_{\mathrm{ijk}} \times \mathrm{DIM}_{\mathrm{ijk}}+\mathrm{E}_{\mathrm{ijk} \mathrm{k}},
\end{gathered}
$$

where $\mu=$ overall mean, $\mathrm{G}_{\mathrm{i}}=$ subgroup effect (HWL or LWL $)_{\mathrm{i}}, \mathrm{C}(\mathrm{G})_{\mathrm{ij}}=$ cow $_{\mathrm{j}}$ nested in $\operatorname{subgroup}_{\mathrm{i}}, \mathrm{DIM}_{\mathrm{ijk}}=$ DIM as the continuous variable, and $\mathrm{E}_{\mathrm{ijk}}=$ random residual. Autoregressive order one (AR 1) was used as a covariance structure in the model.

Glucose and insulin response to GTT over time were analyzed as repeated measurements using the MIXED Procedure of SAS. Time of sampling was analyzed as a fixed effect, whereas cow was analyzed as a random effect in the statistical model.

For the kinetics calculations during the GTT, fractional turnover rate $(\mathrm{k})$, the half-life $\left(\mathrm{T}_{1 / 2}\right.$; the time required for glucose concentration to fall by one-half), and the area under the curve (AUC) at $60 \mathrm{~min}$ after infusion, beginning at $\mathrm{t}=5(5 \mathrm{~min}$ after infusion started), were calculated as described in Zachut et al. (2013). Kinetics calculations, BW, and BCS measurements were analyzed with the General Linear Models (GLM) procedure of SAS. The model included effects of group and cow. Significance was defined at $P<0.05$, and tendencies were reported at $0.05<P<0.10$.

\section{RESULTS}

\section{Magnitude of BW Loss Postpartum Across Lactations}

The average number of lactations for the 92 cows was $4.6 \pm 0.1$ and $4.5 \pm 0.1$ in the HWL and LWL groups, respectively. The average $\mathrm{BW}$ at wk 1 across lactations (1-5) was similar between LWL and HWL cows, at 631.4 and $630.0 \mathrm{~kg}$, respectively $(\mathrm{SEM}=9.6$, $P=0.9$ ), and the BCS at 7 to $10 \mathrm{~d}$ postpartum was 3.18 and 3.22 , respectively $(\mathrm{SEM}=0.035, P=0.4$ ).
The HWL cows lost, on average, $49.9 \mathrm{~kg}$ and the LWL cows lost, on average, $33.8 \mathrm{~kg}(\mathrm{SEM}=2.3)$ by wk $5(P$ $<0.0001$ ), and the percentage of BW loss between wk 1 and 5 across lactations was $7.6 \%$ in the HWL cows compared with $5.3 \%$ in the LWL cows $(\mathrm{SEM}=0.3, P$ $<0.0001)$. Where BW loss was analyzed separately in each lactation, it did not differ between groups in the first lactation, tended to be higher in HWL than in LWL cows in the second lactation $(P=0.06)$, and was higher in HWL than in LWL cows in lactations $3(P$ $=0.03), 4(P<0.0001)$, and $5(P<0.0001$; Figure 1$)$. Furthermore, whereas the average percentage of BW loss between wk 1 and 5 increased from lactation 1 to 5 in the HWL $(5.87,6.49,7.8,8.96$, and $9.81 \%$ in lactations $1,2,34$, and 5 , respectively; $\mathrm{r}=0.99 ; P$ $=0.0005)$, the percentage of $\mathrm{BW}$ loss decreased with lactations in the LWL cows $(7.27,4.83,5.45,4.64$, and $3.64 \%$ in lactations $1,2,3,4$, and 5 , respectively; $\mathrm{r}=$ $-0.88 ; P=0.05)$. The correlation between the BW loss and BCS at calving across lactations was tested and found not significant $(\mathrm{r}=0.06, P=0.3)$.

Analysis of all optional correlations between BW loss in the 5 lactations found that 8 out of 10 pairs

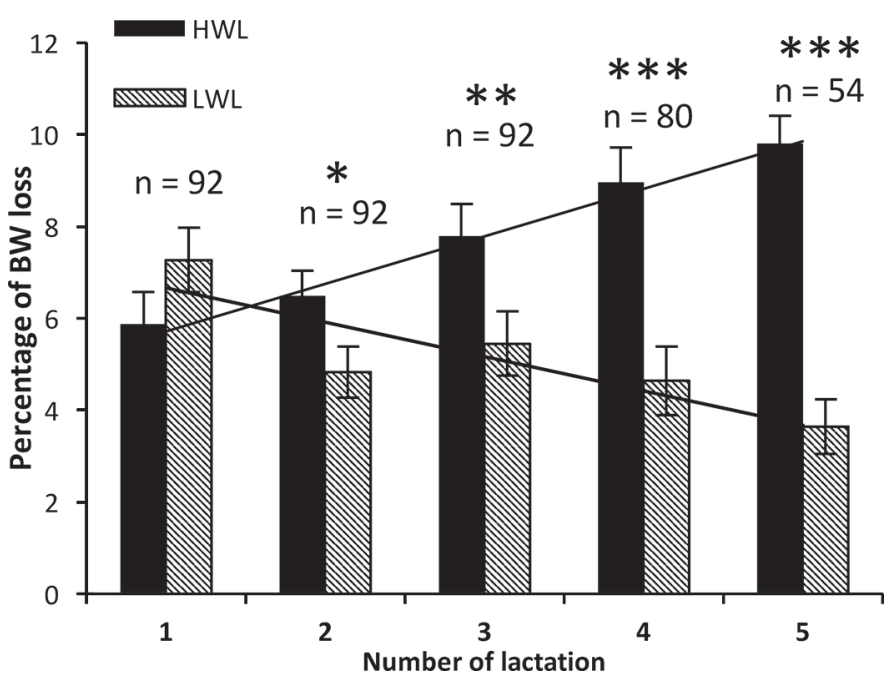

Figure 1. Pattern of BW loss in the first month postpartum of each lactation. Percentage of BW loss from first to fifth week postpartum was calculated for 92 cows in 4 to 5 consecutive lactations. Cows were divided into 2 groups according to BW loss in the last lactation, and this value was used to calculate the average BW loss percentage among all cows (7\%): cows losing more than the average were regarded as high weight loss (HWL, $7-17 \%$ weight loss, $\mathrm{n}=55$, black bars), whereas cows that lost less than the average were considered low weight loss (LWL, -3 to $6 \%$ weight loss, $\mathrm{n}=37$, hatched bars). ${ }^{*} P<$ 0.06 ; ${ }^{*} P<0.05 ;{ }^{* * *} P<0.0001$. The percentage of BW loss increased linearly from lactation 1 to 5 in the HWL $(\mathrm{r}=0.99$; slope $=1.035 ; P$ $=0.0005)$, whereas the percentage of BW loss decreased linearly with lactations in the LWL cows $(\mathrm{r}=-0.88$; slope $=-0.745 ; P=0.05)$. Error bars indicate the SE. 
were positive with low confidence, probably due to the large variance in this relatively small sample $(\mathrm{n}=92)$. Therefore, we tested the correlation between the average BW loss of lactations 1 to 2 and that of lactations 3 to 5 and found a positive correlation between them (r $=0.28 ; P=0.008)$.

\section{Milk Yield and Composition}

For the first $30 \mathrm{~d}$ of lactation, milk yield across lactations (1-5) was higher (33.6 vs. $32.2 \mathrm{~kg} / \mathrm{d}$, respectively, $\mathrm{SEM}=0.45, P=0.04)$ and $4 \% \mathrm{FCM}$ yield was also higher (35.3 vs. $34.3 \mathrm{~kg} / \mathrm{d}$, respectively, $\mathrm{SEM}=0.28, P$ $=0.02)$ in HWL versus LWL cows. The trend toward a repeating pattern of higher milk yield during the first 30 DIM across lactations is presented in Figure 2. No differences were observed between groups in fat (3.91 and $3.96 \%$ ), protein $(3.12$ and $3.15 \%)$, or lactose (4.71 and $4.70 \%)$ percentages across lactations in the HWL and LWL groups, respectively. However, milk yield during 305 DIM across lactations (1-5) was similar for HWL and LWL cows (39.3 vs. $38.9 \mathrm{~kg} / \mathrm{d}$, respectively, SEM = $0.3, P=0.4)$, as was $4 \% \mathrm{FCM}$ yield ( 36.0 vs. $35.7 \mathrm{~kg} / \mathrm{d}$, respectively, $\mathrm{SEM}=0.13, P=0.3)$. Milk fat percentage across lactations $(305 \mathrm{~d})$ tended to be lower in HWL than in LWL cows (3.40 vs. $3.46 \%$, respectively, SEM $=0.02, P=0.1$, milk protein percentage was lower in HWL compared with LWL cows (3.09 vs. 3.15\%, respectively, $\mathrm{SEM}=0.01, P=0.001$ ), and milk lactose percentage was also lower in HWL than in LWL cows (4.82 vs. $4.90 \%$, respectively, $\mathrm{SEM}=0.02, P=0.04$ ).

\section{Reproductive Performance and Health Disorders Postpartum}

All reproductive parameters were calculated for lactations 1 to 4, as data from the fifth lactation was incomplete. Across lactations, the number of days open was $17 \mathrm{~d}$ longer in the HWL versus LWL group (167 vs. $150 \mathrm{~d}, \mathrm{SEM}=5.5, P=0.045)$. In addition, a pattern of extended days open with increasing number of lactation was found in the HWL group (163.1, 158.4, 168.3, $179.8 \mathrm{~d}$ for lactations $1,2,3$ and 4 , respectively; $\mathrm{r}=$ $0.84 ; P=0.15)$, whereas this was not observed for the LWL cows $(\mathrm{r}=0.15 ; P=0.85$; Figure 3$)$.

The calving interval was $20 \mathrm{~d}$ longer in the HWL versus LWL group (440 vs. $420 \mathrm{~d}$, respectively, SEM = $7, P=0.06)$. The number of AI per conception across lactations tended to be higher in HWL cows than in LWL cows (3.1 vs. 2.7, respectively, SEM $=0.17, P=$ 0.1 ).

Conception rates from first, second, and third AI across lactations are presented in Table 1. Conception

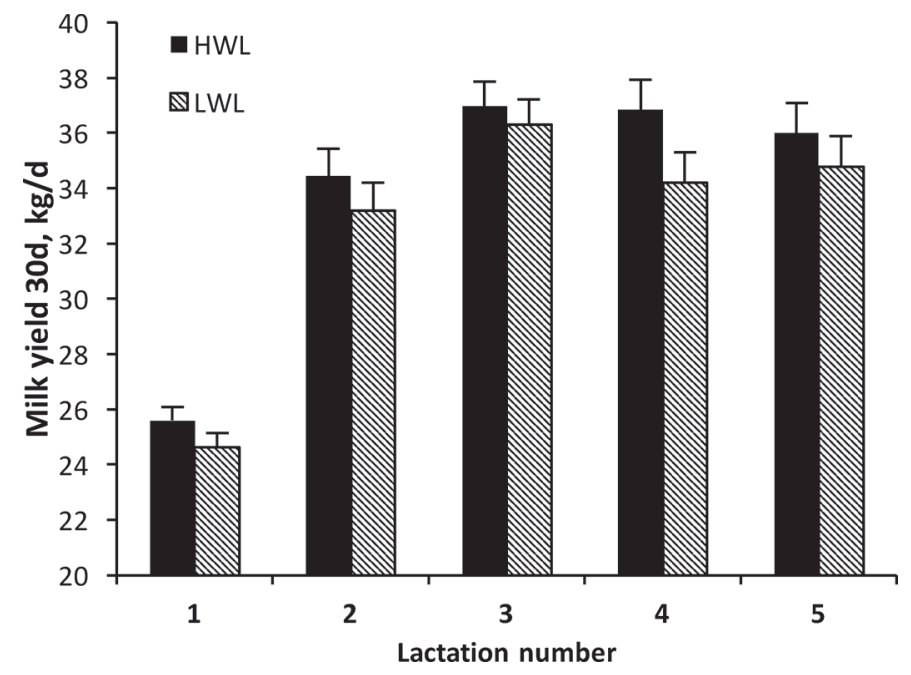

Figure 2. Pattern of milk yield during the first 30 DIM across lactations in cows with high weight loss (HWL, 7-17\% weight loss, $\mathrm{n}=55$, black bars) compared with those with low weight loss (LWL, -3 to $6 \%$ weight loss, $\mathrm{n}=37$, hatched bars). Error bars indicate SE.

rate from first $\mathrm{AI}$ was similar between groups and that from the second AI across lactations was $12.2 \%$ higher in the LWL than in HWL cows $(P=0.1$; Table 1$)$. For lactation numbers 2 to 4 , CR from second AI was $18.7 \%$ higher in LWL than in HWL cows $(P=0.06$; Table 1). In addition, CR from first, second, and third AI across lactations was $9.6 \%$ higher in LWL than in

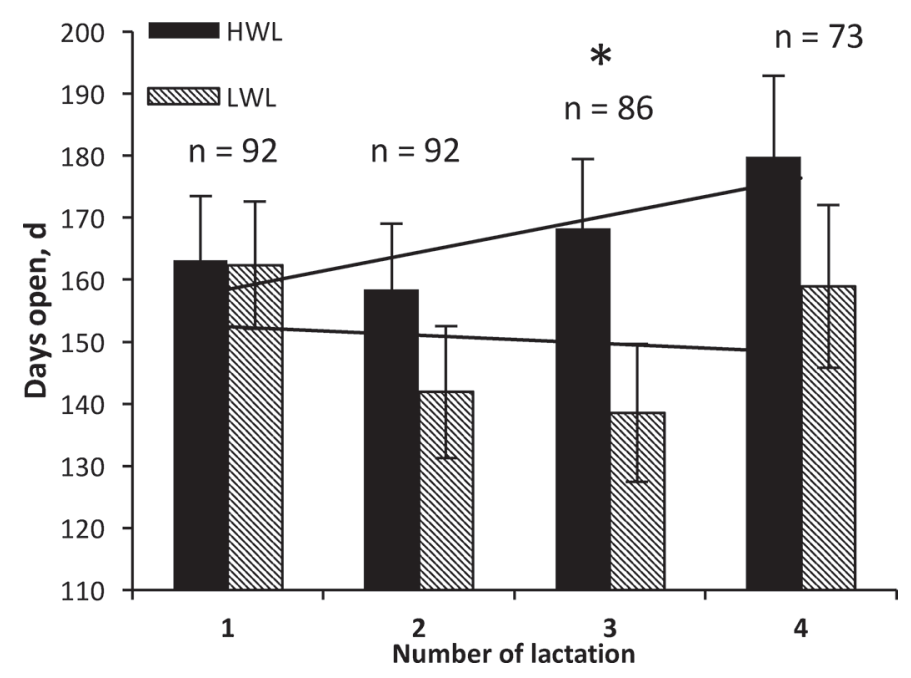

Figure 3. Number of days open across lactations in postpartum cows with high weight loss (HWL, $7-17 \%$ weight loss, $\mathrm{n}=55$, black bars) compared with those with low weight loss (LWL, -3 to $6 \%$ weight loss, $\mathrm{n}=37$, hatched bars). ${ }^{*} P<0.05$. A pattern toward linear increase in days open with increasing number of lactation was found in the HWL group $(\mathrm{r}=0.84$; slope $=6.0 ; P=0.15)$, whereas this was not observed for the LWL cows $(\mathrm{r}=0.15$; slope $=-1.384 ; P=0.85)$. Error bars indicate SE. 
Table 1. Conception rates in cows differing in BW loss postpartum across lactations

\begin{tabular}{|c|c|c|c|}
\hline \multirow[b]{2}{*}{ Item } & \multicolumn{2}{|c|}{ Group $^{1}$} & \multirow[b]{2}{*}{$P$-value } \\
\hline & LWL & HWL & \\
\hline Cows, no. & 37 & 55 & \\
\hline \multicolumn{4}{|l|}{ All lactations, \% (no./total) } \\
\hline 1 st AI & $39.8(55 / 138)$ & $37.0(77 / 208)$ & 0.61 \\
\hline 2nd AI & $37.3(31 / 83)$ & $25.1(33 / 131)$ & 0.10 \\
\hline 1st and 2nd AI & $38.9(86 / 221)$ & $32.4(110 / 339)$ & 0.16 \\
\hline 1st, 2nd, and 3rd AI & $42.1(115 / 273)$ & $32.5(142 / 437)$ & 0.04 \\
\hline \multicolumn{4}{|l|}{ Lactations $2-4, \%$ (no./total) } \\
\hline 1 st AI & $35.6(36 / 101)$ & $31.3(48 / 153)$ & 0.67 \\
\hline 2nd AI & $41.5(27 / 65)$ & $22.8(24 / 105)$ & 0.06 \\
\hline 1st and 2nd AI & $37.9(63 / 166)$ & $27.9(72 / 258)$ & 0.09 \\
\hline 1st, 2nd, and 3rd AI & $42.6(87 / 204)$ & $28.3(96 / 339)$ & 0.03 \\
\hline
\end{tabular}

${ }^{1}$ Percentage of BW loss from first to fifth week postpartum was calculated for 92 cows in 4 to 5 consecutive lactations. Cows were divided into 2 groups according to BW loss in the last lactation, and this value was used to calculate the average BW loss percentage among all cows $(7 \%)$ : cows losing more than the average were regarded as high weight loss (HWL, $7-17 \%$ weight loss, $\mathrm{n}=55$ ), whereas cows that lost less than the average were considered low weight loss (LWL, -3 to $6 \%$ weight loss, $\mathrm{n}=37$ ).

HWL cows $(P=0.04)$, and for lactation numbers 2 to 4 it was $14.3 \%$ higher in LWL than in HWL cows $(P=$ 0.03 ; Table 1).

The incidence of ketosis in all lactations was not significantly different between groups, at $17.3 \%$ in the HWL group compared with $12.8 \%$ in the LWL group $(P=0.45)$ and 21 and $14.8 \%$ in lactations 2 to 5 , respectively $(P=0.4)$. We found no differences in the incidence of parturient paresis across lactations (2.4 and $1.74 \%$ in the HWL and LWL groups, respectively; $P=0.68$ ), metritis (42.7 and $44.1 \%$ in the HWL and LWL groups, respectively; $P=0.77)$, and retained placenta (16.5 and $18.6 \%$ in the HWL and LWL groups, respectively; $P=0.58)$.

\section{Metabolic Characterization of HWL and LWL Cows}

The following results are from 11 cows, as 1 cow was excluded from the analyses due to severe illness on d 10 postpartum that precluded performing a GTT. Cows were divided into 2 subgroups according to the magnitude of their BW loss from wh 1 to 5 , similar to the criteria of the division described above for the large group (92 cows). Five cows were defined as c-HWL and 6 cows as c-LWL (lactation number was 3.2 and 2.3 in $\mathrm{c}-\mathrm{HWL}$ and c-LWL, respectively, $\mathrm{SEM}=0.36, P$ $=0.12$ ). The percentage of BW loss from wk 1 to 5 , by definition, was greater in c-HWL than in c-LWL (9 vs. $5 \%$, respectively, $\mathrm{SEM}=0.6, P=0.002$ ), and at wk 5 the c-HWL cows had a significantly lower BCS than the c-LWL cows (2.4 vs. 3.2 units in c-HWL and c-LWL, respectively, SEM $=0.14, P=0.006)$. Cows from both subgroups had a similar BCS at wk 1 (3.5 and 3.4 units in c-HWL and c-LWL, respectively, SEM
$=0.14, P=0.7)$, and similar BW at wk 1 (642.6 and $644.5 \mathrm{~kg}$ in $\mathrm{c}-\mathrm{HWL}$ and $\mathrm{c}-\mathrm{LWL}$, respectively, SEM = 34.0, $P=0.96)$.

Prepartum DMI was $5 \%$ higher in c-HWL than cLWL cows, with no differences in DMI during the first 30 DIM between groups (Table 2). Milk yields during the first 30 DIM were not different between groups, and milk 4\% FCM yields were similar between c-HWL and c-LWL during this time $(33.9$ and $33.8 \mathrm{~kg} / \mathrm{d}$, respectively, SEM $=7.0, P=0.99)$, as well as for 60 DIM $(36.2$ and $35.7 \mathrm{~kg} / \mathrm{d}$, respectively, $\mathrm{SEM}=6.0, P$ $=0.96)$.

No differences in prepartum plasma fatty acid concentrations were found between groups (data not shown), but the postpartum fatty acid concentrations in c-HWL cows were higher than in c-LWL cows (Table 2). Plasma insulin and glucose concentrations did not differ between groups either pre- or postpartum (data not shown). However, the average calculated revised quantitative insulin sensitivity check index (RQUICKI; Holtenius and Holtenius, 2007) during the transition period tended to be lower in c-HWL cows than in c-LWL cows $(0.369$ vs. 0.380 , respectively, $\mathrm{SEM}=0.005, P=0.16)$. Plasma concentrations of the oxidative stress marker MDA tended to be higher in cHWL than in c-LWL cows during the transition period (Table 2).

\section{Response to GTT}

The response to the GTT was examined both prepartum (14 d before expected calving) and postpartum (10 DIM). The c-HWL cows showed increased insulin secretion following GTT prepartum $(P=0.008$; Figure 

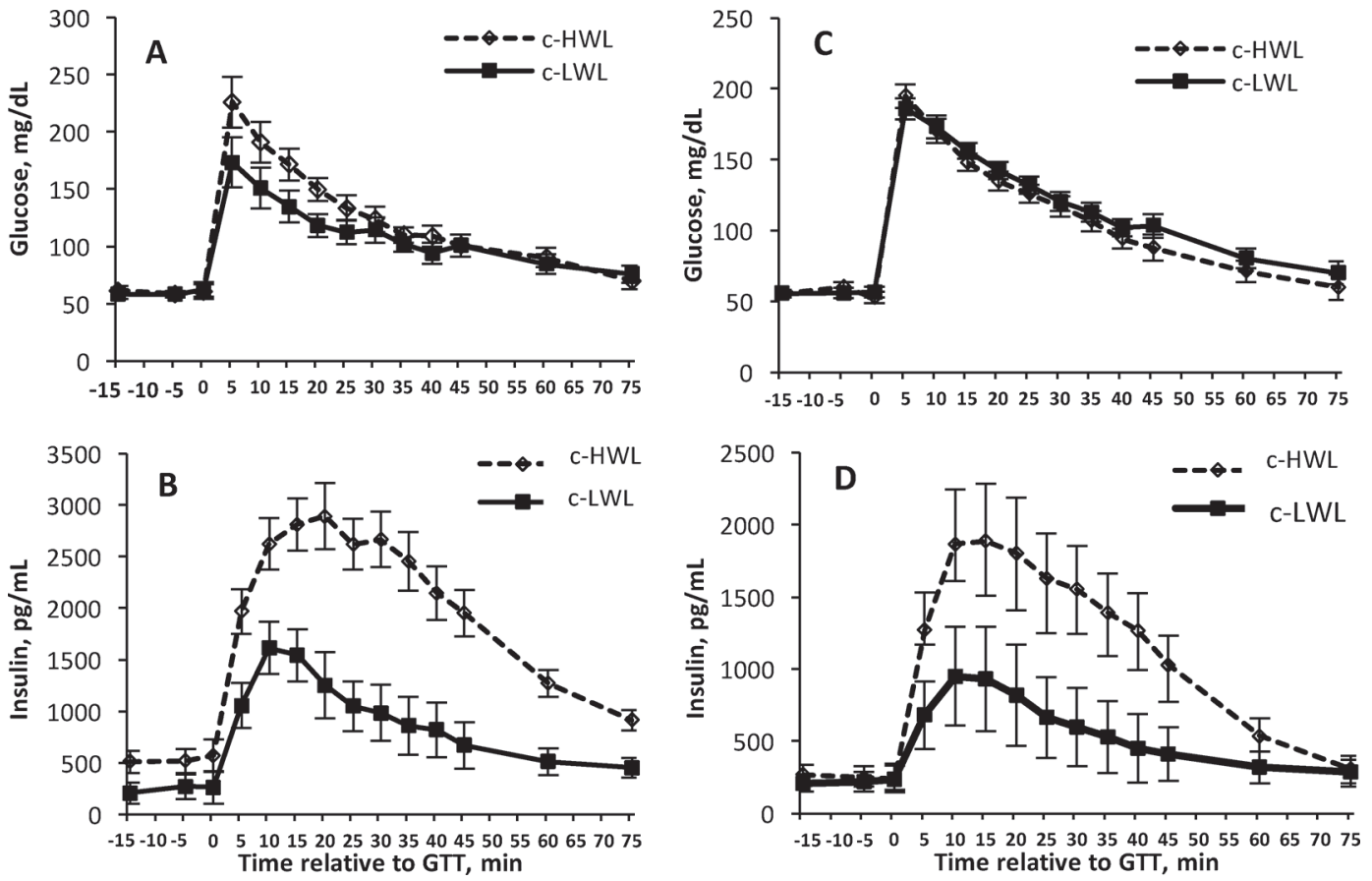

Figure 4. Plasma glucose and insulin concentrations in response to glucose tolerance test (GTT) in cows in late pregnancy (A, B) and early lactation (C, D). Plasma glucose (A, C) and insulin (B, D) concentrations were determined at the indicated times in response to GTT performed on 260-d-pregnant, nonlactating cows (prepartum), and then again at $10 \mathrm{~d}$ after calving (postpartum). Data are LSM \pm SEM. Insulin secretion following GTT was higher in the high weight loss group (c-HWL) than in the low weight loss group (c-LWL) prepartum $(P=0.008)$, and tended to be higher postpartum $(P=0.07)$.

4), and a tendency toward increased insulin secretion postpartum compared with c-LWL cows $(P=0.07$; Figure 4). Plasma glucose concentrations during GTT did not differ between groups either pre- or postpartum (Figure 4). Average AUC for insulin secretion was higher prepartum $(25,220.4$ vs. $11,228.5 \mathrm{pg} / \mathrm{mL}$ per min, respectively, $\mathrm{SEM}=2251.5, P=0.004)$, and tended to be higher postpartum $(14,820.5$ vs. $7050.3 \mathrm{pg} / \mathrm{mL}$ per min, respectively, $\mathrm{SEM}=2788.3, P=0.07)$ in $\mathrm{c}$ -
HWL than in c-LWL cows. No differences in glucose AUC, turnover rate (k-values), or half-life $\left(\mathrm{T}_{1 / 2}\right)$ were observed between groups (data not shown).

\section{DISCUSSION}

In the present retrospective study, we demonstrate a consistent pattern of postpartum BW loss in highyielding dairy cows across lactations, which was associ-

Table 2. Intake, milk yield, and energy balance in cows differing in BW loss postpartum

\begin{tabular}{lcccc}
\hline & \multicolumn{2}{c}{ Group $^{1}$} & & \\
\cline { 2 - 3 } Item & c-HWL & c-LWL & \multirow{2}{*}{ SEM } & P-value \\
\hline Cows, no. & 5 & 6 & & \\
Prepartum DMI, kg/d & 12.6 & 12.0 & 0.2 & 0.05 \\
DMI during 30 DIM, kg/d & 21.9 & 21.2 & 0.8 & 0.6 \\
Milk yield during 30 DIM, kg/d & 31.6 & 36.8 & 8.8 & 0.7 \\
Energy balance during 30 DIM, Mcal/d & -4.7 & -2.5 & 0.9 & 0.17 \\
Energy balance nadir, Mcal/d & -16.3 & -11.8 & 2.2 & 0.19 \\
Plasma fatty acids from 1 to 21 DIM, $\mu$ Eq/L & 589.7 & 419.3 & 32.7 & 0.004 \\
Plasma MDA ${ }^{2}$ from -14 to 14 DIM, nM & 149.7 & 108.4 & 14.1 & 0.08 \\
\hline
\end{tabular}

${ }^{1}$ Twelve cows were divided into 2 subgroups according to the magnitude of their BW loss from wk 1 to 5 , similar to the criteria of the division for the large group. One cow was excluded due to severe illness; 5 cows were defined as c-HWL (companion high weight loss) and 6 cows as c-LWL (companion low weight loss). The percentage of BW loss was $9 \%$ in the $\mathrm{c}-\mathrm{HWL}$ and $5 \%$ in $\mathrm{c}-\mathrm{LWL}(\mathrm{SEM}=0.6, P=0.002)$.

${ }^{2} \mathrm{MDA}=$ malondialdehyde. 
ated with fertility performance but not with the incidence of metabolic disorders. Interspecies variation and repeatability of the response to metabolic stress during the same lactation were recently investigated in dairy cows (Gross and Bruckmaier, 2015) and goats (Friggens et al., 2016). In addition, Ollion et al. (2016) examined the trade-offs between life functions in cows, which were tested during 1 lactation, and found 4 clusters of cows representing 4 types of priorities between milk production and other life functions, such as reproduction. The present study is the first to demonstrate a repetitive pattern of postpartum BW loss in high-yielding cows across several lactations, suggesting an intrinsic trait that may have a genetic basis as was demonstrated by Friggens et al. (2007).

\section{Milk Yield and Milk Solids}

The milk and FCM yields during the first 30 DIM were higher in the HWL than in the LWL cows, but they did not differ between groups for $305 \mathrm{~d}$ of lactation. The HWL group can be defined as cows that prioritize lactation and mobilize more body mass to meet energy requirements relative to the LWL cows, as previously suggested (Ollion et al., 2016). Considerable phenotypic variation is known to exist among highyielding dairy cows with respect to tissue mobilization in early lactation (Chilliard et al., 2000; Hammon et al., 2009). Moreover, cows with high genetic merit have been suggested to mobilize more body reserves than those with low genetic merit (McNamara and Hillers, 1986; Pryce et al., 2001). However, the yield differences between groups in the present study were only evident in early lactation, and reduced as lactation advanced. This might indicate similar genetic merit for milk production between the groups; indeed, the predicted transmitting ability of these cows was not different between groups. However, the mobilization of body mass in the HWL cows in early lactation may enhance energy availability and, therefore, trigger higher milk production than in their LWL counterparts, suggesting different priorities in early lactation between groups. Body mass mobilization becomes less relevant later in lactation, when cows consume enough to meet their nutritional requirements. Obese cows tend to mobilize more body tissue during early lactation, defined as fat cow syndrome, with adverse consequences on cow health (Morrow, 1976). However, the observed differences in BW loss between groups in our study occurred even though the cows of both groups started the lactation with equal BW and BCS. Also, we found no correlation between the BW loss until wk 5 and BCS at calving. In agreement with our findings, Weber et al. (2013) found that postpartum mobilization of subcutaneous fat does not depend on the degree of fatness at calving time, as also described elsewhere (Janovick and Drackley, 2010). Together, these findings indicate an intrinsic trait rather than a response to a given physiological state (such as obesity) in the specified lactation.

Interestingly, we found a linear increase in the magnitude of BW loss with lactations in the HWL group, with a corresponding moderate decrease in the LWL group (Figure 1). This occurred even though the average BW loss in the first lactation was not significantly different between groups. The first lactation is characterized by continuous growth of skeleton and body size, which may confound the use of BW measurements as an indicator of fat reserves in this lactation. In addition, it might be that during body growth, the intrinsic BW loss trait is expressed to a lesser extent. In humans, repeat episodes of weight loss and regain are known as weight cycling (Atkinson et al., 1994). One clinical definition of weight cycling is a $5 \%$ weight loss and regain (Taing et al., 2012), which is very similar to the extent of BW loss observed in dairy cows in our study ( $5-7 \%$ of BW). It should be noted that in humans, weight cycling does not include BW fluctuations related to pregnancy, which are very different from the postpartum BW loss discussed in our study in a high milk producing animal; nevertheless, the negative energy balance in postpartum dairy cows has some similar characteristics to BW loss in humans due to nutritional restrictions. In humans, weight cycling may promote insulin resistance and diabetes either directly or by favoring weight gain (Yatsuya et al., 2003; Field et al., 2004; Zhang et al., 2005). Our present findings that c-HWL cows have increased insulin secretion following GTT and a tendency toward lower RQUICKI values, implying reduced insulin sensitivity in these animals, are in accordance with the impaired systemic glucose tolerance (Anderson et al., 2013) and insulin resistance (Montani et al., 2006) demonstrated in weight cycling in other species.

\section{Reproductive Performance}

In general, fertility performance across lactations was lower in the HWL cows than in the LWL cows. The association between milk production and fertility in highyielding dairy cows has been investigated in many studies with inconsistent results. Several studies have found a negative association between milk yield and fertility traits (Hoekstra et al., 1994; Darwash, and Lamming, 1997; Beam and Butler, 1999), whereas others did not find any relationship between the aforementioned traits (Snijders et al., 2000; Morton 2001; Patton et al., 
2007). Moreover, evidence exists that genetic selection for increased milk yield adversely affects fertility (Pryce et al., 2004), but not necessarily phenotypic milk yield. Conversely, several studies found a positive association between milk yield variables in early lactation and reproductive performance (Domecq et al., 1997; Buckley et al., 2003). In the current study, milk yield in of HWL cows was higher than that of LWL cows in early lactation, but similar 305-d yields were found. Buckley et al. (2003) demonstrated that cows with a very high 100-d cumulative milk yield as a proportion of the estimated 305-d cumulative milk yield were less likely to be pregnant from first service. Madsen (1975) suggested that high milk yield at the beginning of lactation puts a high physiological stress on cows, often leading to lower reproductive performance, which is in accordance with our findings in the HWL cows.

The HWL group, by definition, lost more BW in early lactation than the LWL group. In contrast to milk yield, the negative association between the magnitude of BW mobilization in early lactation and reproductive performance in dairy cows has been well documented in many studies. However, body mass loss in most of those studies was evaluated by monitoring BCS (Domecq et al., 1997; Santos et al., 2009; Carvalho et al., 2014), and only a very few studies used BW measurements. In the present study, we used the automatically generated daily BW records of 416 lactations and found a consistent pattern within cows between high BW loss and low fertility across lactations. A negative association between reproductive traits and BCS measurements has been found in many studies (Butler and Smith, 1989; Domecq et al., 1997; Carvalho et al., 2014), and, in a large-scale study, Santos et al. (2009) found that this relationship is more profound for changes in BCS between calving and 70 DIM than for BCS measurements at calving or insemination time. Vercouteren et al. (2015) found a negative association between BW loss until 14 DIM and cyclicity by 21 postpartum. In our study, a negative association was found between the percentage of BW changes between wk 1 and 5 postpartum and reproduction characteristics across lactations. Several studies have investigated the heritability and repeatability of traditional and endocrine fertility traits, finding moderate values (Weller and Ezra, 2004; Tenghe et al., 2016). Recently, 2 studies found that cows with good genetic merit for fertility traits had better fertility performance while maintaining a higher threshold BCS level (Cummins et al., 2012; Moore et al., 2014). This occurred despite maintaining a higher milk yield throughout lactation, which emphasizes the close correlation between genetic merit for fertility traits, BCS, and phenotypic fertility performance (Cummins et al., 2012; Moore et al., 2014). The consistent pattern of BW loss that was linked to fertility traits in the present study may suggest that the heritability of fertility traits found in other publications is closely related to the repeatability of BW loss in early lactation; however, this hypothesis needs to be further explored.

The relatively high incidence of metabolic disorders and the reproductive system illness may be attributed to the intensive veterinary follow-up of the cows, which is typical to the Israeli dairy herd management. In the present study, no differences were observed in all metabolic disorders or reproductive system diseases between groups, although they were associated with BW loss (Drackley, 1999).

\section{Possible Physiological Mechanism}

In accordance with the higher magnitude of $\mathrm{BW}$ loss, the c-HWL cows also lost more BCS units than c-LWL cows, suggesting that BW loss is a satisfactory indicator of fat mobilization, which is in accordance with other studies (Berry et al., 2006; Thorup et al., 2012 ). Therefore, we can assume that the HWL cows in the large data set of cows $(n=92)$ mobilized more fat during early lactation compared with their LWL counterparts. We did not find any differences in postpartum DMI between c-HWL and c-LWL cows, suggesting that the differences in BW loss may not be directly related to energy intake.

Fat mobilization lead to increased fatty acid plasma concentrations. Notably, the c-HWL cows had similar BCS and plasma fatty acid concentrations prepartum; therefore, the differences in DMI were not related to degree of fatness during late pregnancy. As c-HWL cows had a similar pattern of BCS during late pregnancy and at calving, plasma fatty acid concentrations only differed between groups postpartum, when the difference in fat mobilization occurred. The elevated plasma MDA concentrations found in the c-HWL cows are in accordance with the higher fatty acids in these cows, as fat mobilization increases oxidative stress (Bradford et al., 2015). Increased circulating fatty acids can induce insulin resistance in dairy cows (Pires et al., 2007); interestingly, RQUICKI values tended to be lower in c-HWL cows, suggesting decreased whole-body insulin sensitivity in these cows compared with c-LWL (Holtenius and Holtenius, 2007). Similarly, Weber et al. (2013) found increased RQUICKI values for cows with medium versus high LFC, and Holtenius and Holtenius (2007) demonstrated a negative linear relationship between adiposity and RQUICKI values. Moreover, in response to GTT, the c-HWL cows secreted much more insulin than the c-LWL cows (Figure 4), indicating of higher 
pancreatic insulin secretion to achieve normal glucose clearance. Taken together, these findings suggest that c-HWL are more insulin-resistant at the whole-body level than c-LWL cows, which is in accordance with the differential insulin response in adipose tissue of cows that differ in degree of BW loss (Zachut et al., 2013).

As no differences in DMI or efficiency (milk/DMI and FCM/DMI) were found between groups, one possibility for the increased BW loss could be related to differences in basal metabolic rate (BMR). Metabolic rate varies considerably between individuals and populations (Burton et al., 2011; White and Kearney, 2013) and is linked to growth, reproduction, and survival (Burton et al., 2011). Within-species variations in BMR and its components have a clear genetic signature and are functionally linked to key metabolic processes (Konarzewski and Książek, 2013). Also, a repeatability in between-individual variations in BMR has been reported (Rønning et al., 2005). In the present study, HWL cows showed reduced reproductive performance while maintaining milk production, suggesting that the increased energy expenditure might be related to their metabolic rate. Therefore, subpopulations of dairy cows with different BMR may exist, an issue that requires further investigation.

\section{CONCLUSIONS}

This is the first study to demonstrate a consistent magnitude of $\mathrm{BW}$ loss in dairy cows across lactations. An interesting linear increase in BW loss as lactations progressed was also found in the HWL cows, with a moderate decreasing trend in the LWL cows. The differences between groups in BW loss were evident only from the second lactation on, suggesting the possibility of defining cows with high or low BW loss at this time. The degree of BW loss was associated with fertility performance of cows across lactations. In a smaller study, we showed that cows that lost more BW postpartum had lower whole-body insulin sensitivity. The degree of BW loss postpartum, regardless of the genetic merit for milk production, seems to be an intrinsic trait that represents the variation in trade-off toward tissue mobilization between cows, and affects reproductive performance. These findings warrant further research on the characteristics and governing mechanisms of the suggested intrinsic trait.

\section{ACKNOWLEDGMENTS}

The authors thank the Volcani dairy farm (Rishon LeZion, Israel) staff for their assistance with animal care in the companion study. This work was partly funded by the Israeli Dairy Milk Association (Yehud, Israel; 362-0460).

\section{REFERENCES}

Anderson, E. K., D. A. Gutierrez, A. Kennedy, and A. H. Hasty. 2013. Weight cycling increases T-cell accumulation in adipose tissue and impairs systemic glucose tolerance. Diabetes 62:3180-3188. https://doi.org/10.2337/db12-1076.

Atkinson, R. L., W. H. Dietz, J. P. Foreyt, N. J. Goodwin, J. O. Hill, J. Hirsch, F. X. Pi-Sunyer, R. L. Weinsier, R. Wing, J. H. Hoofnagle, J. Everhart, V. S. Hubbard, and S. Z. Yanovski. 1994. Weight cycling. JAMA 272:1196-1202. https://doi.org/10.1001/ jama.1994.03520150064038.

Beam, S. W., and W. R. Butler. 1999. Effects of energy balance on follicular development and first ovulation in postpartum dairy cows. J. Reprod. Fertil. Suppl. 54:411-424.

Bell, A. W., and D. E. Bauman. 1997. Adaptations of glucose metabolism during pregnancy and lactation. J. Mammary Gland Biol. Neoplasia 2:265-278.

Berry, D. P., K. A. Macdonald, J. W. Penno, and J. R. Roche. 2006. Association between body condition score and live weight in pasture-based Holstein-Friesian dairy cows. J. Dairy Res. 73:487-491. https://doi.org/10.1017/S0022029906002020.

Bradford, B. J., K. Yuan, J. K. Farney, L. K. Mamedova, and A. J. Carpenter. 2015. Invited review: Inflammation during the transition to lactation: New adventures with an old flame. J. Dairy Sci. 98:6631-6650. https://doi.org/10.3168/jds.2015-9683.

Buckley, F., K. O'Sullivan, J. F. Mee, R. D. Evans, and P. Dillon. 2003. Relationships among milk yield, body condition, cow weight, and reproduction in spring-calved Holstein-Friesians. J. Dairy Sci. 86:2308-2319. https://doi.org/10.3168/jds.S0022-0302(03)738235.

Burton, T., S. S. Killen, J. D. Armstrong, and N. B. Metcalfe. 2011. What causes intraspecific variation in resting metabolic rate and what are its ecological consequences? Proc. Biol. Sci. 278:34653473. https://doi.org/10.1098/rspb.2011.1778.

Butler, W. R., and R. D. Smith. 1989. Interrelationships between energy balance and postpartum reproductive function in dairy cattle. J. Dairy Sci. 72:767-783. https://doi.org/10.3168/jds.S00220302(89)79169-4.

Carvalho, P. D., A. H. Souza, M. C. Amundson, K. S. Hackbart, M. J. Fuenzalida, M. M. Herlihy, H. Ayres, A. R. Dresch, L. M. Vieira, J. N. Guenther, R. R. Grummer, P. M. Fricke, R. D. Shaver, and M. C. Wiltbank. 2014. Relationships between fertility and postpartum changes in body condition and body weight in lactating dairy cows. J. Dairy Sci. 97:3666-3683. https://doi.org/10.3168/ jds.2013-7809.

Chilliard, Y., A. Ferlay, Y. Faulconnier, M. Bonnet, J. Rouel, and F. Bocquier. 2000. Adipose tissue metabolism and its role in adaptations to undernutrition in ruminants. Proc. Nutr. Soc. 59:127-134

Cummins, S. B., P. Lonergan, A. C. O. Evans, D. P. Berry, R. D. Evans, and S. T. Butler. 2012. Genetic merit for fertility traits in Holstein cows: I. Production characteristics and reproductive efficiency in a pasture-based system. J. Dairy Sci. 95:1310-1322.

Darwash, A. O., G. E. Lamming, and J. A. Wooliams. 1997. The phenotypic association between the interval to postpartum ovulation and traditional measures of fertility in dairy cattle. Anim. Sci. 65:9-16.

Domecq, J. J., A. L. Skidmore, J. W. Lloyd, and J. B. Kaneene. 1997. Relationship between body condition scores and conception at first artificial insemination in a large dairy herd of high yielding Holstein cows. J. Dairy Sci. 80:113-120. https://doi.org/10.3168/jds. S0022-0302(97)75918-6.

Drackley, J. K. 1999. ADSA Foundation Scholar Award. Biology of dairy cows during the transition period: The final frontier? J. Dairy Sci. 82:2259-2273. 
Edmonson, A. J., I. J. Lean, L. D. Weaver, T. Farver, and G. Webster. 1989. A body condition scoring chart for Holstein dairy cows. J. Dairy Sci. 72:68-78. https://doi.org/10.3168/jds.S00220302(89)79081-0.

Feldman, E. 2004. Animal models of diabetic complications consortium (AMDCC protocols). Version 1:1-3. www.amdcc.org/shared/ showFile.aspx?doctypeid $=3 \&$ docid $=33$.

Field, A. E., J. E. Manson, N. Laird, D. F. Williamson, W. C. Willett, and G. A. Colditz. 2004. Weight cycling and the risk of developing type 2 diabetes among adult women in the United States. Obes. Res. 12:267-274. https://doi.org/10.1038/oby.2004.34.

Friggens, N. C., P. Berg, P. Theilgaard, I. R. Korsgaard, K. L. Ingvartsen, P. Løvendahl, and J. Jensen. 2007. Breed and parity effects on energy balance profiles through lactation: Evidence of genetically driven body energy change. J. Dairy Sci. 90:5291-5305. https://doi.org/10.3168/jds.2007-0173.

Friggens, N. C., C. Duvaux-Ponter, M. P. Etienne, T. Mary-Huard, and P. Schmidely. 2016. Characterizing individual differences in animal responses to a nutritional challenge: Toward improved robustness measures. J. Dairy Sci. 99:2704-2718. https://doi. org/10.3168/jds.2015-10162.

Goff, J. P., and R. L. Horst. 1997. Physiological changes at parturition and their relationship to metabolic disorders. J. Dairy Sci. 80:1260-1268. https://doi.org/10.3168/jds.S0022-0302(97)76055-

Gross, J. J., and R. M. Bruckmaier. 2015. Repeatability of metabolic responses to a nutrient deficiency in early and mid lactation and implications for robustness of dairy cows. J. Dairy Sci. 98:86348643. https://doi.org/10.3168/jds.2014-9246.

Hammon, H. M., G. Stürmer, F. Schneider, A. Tuchscherer, H. Blum, T. Engelhard, A. Genzel, R. Staufenbiel, and W. Kanitz. 2009. Performance and metabolic and endocrine changes with emphasis on glucose metabolism in high-yielding dairy cows with high and low fat content in liver after calving. J. Dairy Sci. 92:1554-1566. https://doi.org/10.3168/jds.2008-1634.

Hoekstra, J., A. W. Van der Lugt, J. H. J. Van der Werf, and W. Ouweltjes. 1994. Genetic and phenotypic parameters for milk production and fertility traits in upgraded dairy cattle. Livest. Prod. Sci. 40:225-232.

Holtenius, P., and K. Holtenius. 2007. A model to estimate insulin sensitivity in dairy cows. Acta Vet. Scand. 49:29. https://doi. org/10.1186/1751-0147-49-29.

International Dairy Federation. 2000. IDF standard 141c:2000: Determination of milk fat, protein and lactose content-Guidance on the operation of mid-infrared instruments. International Dairy Federation, Brussels, Belgium.

Janovick, N. A., and J. K. Drackley. 2010. Prepartum dietary management of energy intake affects postpartum intake and lactation performance by primiparous and multiparous Holstein cows. J. Dairy Sci. 93:3086-3102. https://doi.org/10.3168/jds.2009-2656.

Konarzewski, M., and A. Książek. 2013. Determinants of intra-specific variation in basal metabolic rate. J. Comp. Physiol. B 183:27-41. https://doi.org/10.1007/s00360-012-0698-z.

Madsen, O. 1975. A comparison of some suggested measures of persistency of milk yield in dairy cows. Anim. Prod. 20:191-197.

Mallard, B. A., J. C. Dekkers, M. J. Ireland, K. E. Leslie, S. Sharif, C. L. Vankampen, L. Wagter, and B. N. Wilkie. 1998. Alteration in immune responsiveness during the peripartum period and its ramification on dairy cow and calf health. J. Dairy Sci. 81:585-595.

McNamara, J. P. 2012. Ruminant Nutrition Symposium: A systems approach to integrating genetics, nutrition, and metabolic efficiency in dairy cattle. J. Anim. Sci. 90:1846-1854. https://doi. org/10.2527/jas.2011-4609

McNamara, J. P., and J. K. Hillers. 1986. Regulation of bovine adipose tissue metabolism during lactation. 2. Lipolysis response to milk production and energy intake. J. Dairy Sci. 69:3042-3050. https:// doi.org/10.3168/jds.S0022-0302(86)80767-6.

Montani, J.-P., A. K. Viecelli, A. Prévot, and A. G. Dulloo. 2006. Weight cycling during growth and beyond as a risk factor for later cardiovascular diseases: the "repeated overshoot" theory. Int.
J. Obes. (Lond.) 30(Suppl 4):S58-S66. https://doi.org/10.1038/ sj.ijo.0803520.

Moore, S. G., T. Fair, P. Lonergan, and S. T. Butler. 2014. Genetic merit for fertility traits in Holstein cows: IV. Transition period, uterine health, and resumption of cyclicity. J. Dairy Sci. 97:27402752 .

Morrow, D. A. 1976. Fat cow syndrome. J. Dairy Sci. 59:1625-1629.

Morton, J. M. 2001. High geneticmerit and high-producing dairy cows in commercial Australian herds don't have substantially worse reproductive performance. Br. Soc. Anim. Sci. Occ. Publ. No. $26: 305-311$.

NRC. 1989. Nutrient Requirements of Dairy Cattle. 6th rev. ed. Natl. Acad. Sci., Washington, DC.

NRC. 2001. Nutrient Requirements of Dairy Cattle. 7th rev. ed. Natl. Acad. Sci., Washington, DC.

Ollion, E., S. Ingrand, L. Delaby, J. M. Trommenschlager, S. ColetteLeurent, and F. Blanc. 2016. Assessing the diversity of trade-offs between life functions in early lactation dairy cows. Livest. Sci. 183:98-107. https://doi.org/10.1016/j.livsci.2015.11.016.

Onken, J., G. Hobgood, and S.L. Sheilds, and J.P.M. 2011. Use of a mechanistic, dynamic model of metabolism to investigate the biological basis for variation in genetics of feed conversion efficiency in lactating dairy cattle. J. Dairy Sci. 94(E-Suppl.):509-510. (Abstr.)

Patton, J., D. A. Kenny, S. McNamara, J. F. Mee, F. P. O'Mara, M. G. Diskin, and J. J. Murphy. 2007. Relationships among milk production, energy balance, plasma analytes, and reproduction in Holstein-Friesian cows. J. Dairy Sci. 90:649-658. https://doi. org/10.3168/jds.S0022-0302(07)71547-3.

Pires, J. A. A., A. H. Souza, and R. R. Grummer. 2007. Induction of hyperlipidemia by intravenous infusion of tallow emulsion causes insulin resistance in Holstein cows. J. Dairy Sci. 90:2735-2744. https://doi.org/10.3168/jds.2006-759.

Pryce, J. E., M. P. Coffey, and G. Simm. 2001. The relationship between body condition score and reproductive performance. J. Dairy Sci. 84:1508-1515. https://doi.org/10.3168/jds.S00220302(01)70184-1.

Pryce, J. E., M. D. Royal, P. C. Garnsworthy, and I. L. Mao. 2004. Fertility in the high-producing dairy cow. Livest. Prod. Sci. 86:125-135. https://doi.org/10.1016/S0301-6226(03)00145-3.

Rønning, B., B. Moe, and C. Bech. 2005. Long-term repeatability makes basal metabolic rate a likely heritable trait in the zebra finch Taeniopygia guttata. J. Exp. Biol. 208:4663-4669. https:// doi.org/10.1242/jeb.01941.

Santos, J. E. P., H. M. Rutigliano, and M. F. Sá Filho. 2009. Risk factors for resumption of postpartum estrous cycles and embryonic survival in lactating dairy cows. Anim. Reprod. Sci. 110:207-221. https://doi.org/10.1016/j.anireprosci.2008.01.014.

Snijders, S. E., P. Dillon, D. O'Callaghan, and M. P. Boland. 2000. Effect of genetic merit, milk yield, body condition and lactation number on in vitro oocyte development in dairy cows. Theriogenology 53:981-989. https://doi.org/10.1016/S0093-691X(00)00244-2.

Taing, K. Y., C. I. Ardern, and J. L. Kuk. 2012. Effect of the timing of weight cycling during adulthood on mortality risk in overweight and obese postmenopausal women. Obesity (Silver Spring) 20:407413. https://doi.org/10.1038/oby.2011.207.

Tenghe, A. M. M., A. C. Bouwman, B. Berglund, E. Strandberg, D. J. de Koning, and R. F. Veerkamp. 2016. Genome-wide association study for endocrine fertility traits using single nucleotide polymorphism arrays and sequence variants in dairy cattle. J. Dairy Sci. 99:5470-5485. https://doi.org/10.3168/jds.2015-10533.

Thorup, V. M., D. Edwards, and N. C. Friggens. 2012. On-farm estimation of energy balance in dairy cows using only frequent body weight measurements and body condition score. J. Dairy Sci. 95:1784-1793. https://doi.org/10.3168/jds.2011-4631.

Vercouteren, M. M. A. A., J. H. J. Bittar, P. J. Pinedo, C. A. Risco, J. E. P. Santos, A. Vieira-Neto, and K. N. Galvão. 2015. Factors associated with early cyclicity in postpartum dairy cows. J. Dairy Sci. 98:229-239. https://doi.org/10.3168/jds.2014-8460.

Weber, C., C. Hametner, A. Tuchscherer, B. Losand, E. Kanitz, W. Otten, S. P. Singh, R. M. Bruckmaier, F. Becker, W. Kanitz, and 
H. M. Hammon. 2013. Variation in fat mobilization during early lactation differently affects feed intake, body condition, and lipid and glucose metabolism in high-yielding dairy cows. J. Dairy Sci. 96:165-180. https://doi.org/10.3168/jds.2012-5574.

Weller, J. I., and E. Ezra. 2004. Genetic analysis of the Israeli Holstein dairy cattle population for production and nonproduction traits with a multitrait animal model. J. Dairy Sci. 87:1519-1527. https://doi.org/10.3168/jds.S0022-0302(04)73303-2.

White, C. R., and M. R. Kearney. 2013. Determinants of inter-specific variation in basal metabolic rate. J. Comp. Physiol. B 183:1-26. https://doi.org/10.1007/s00360-012-0676-5.

Yatsuya, H., K. Tamakoshi, T. Yoshida, Y. Hori, H. Zhang, M. Ishikawa, S. Zhu, T. Kondo, and H. Toyoshima. 2003. Association between weight fluctuation and fasting insulin concentration in Japanese men. Int. J. Obes. Relat. Metab. Disord. 27:478-483. https:// doi.org/10.1038/sj.ijo.0802221.
Zachut, M. 2015. Defining the adipose tissue proteome of dairy cows to reveal biomarkers related to peripartum insulin resistance and metabolic status. J. Proteome Res. 14:2863-2871. https://doi. org/10.1021/acs.jproteome.5b00190.

Zachut, M., H. Honig, S. Striem, Y. Zick, S. Boura-Halfon, and U. Moallem. 2013. Periparturient dairy cows do not exhibit hepatic insulin resistance, yet adipose-specific insulin resistance occurs in cows prone to high weight loss. J. Dairy Sci. 96:5656-5669.

Zhang, H., K. Tamakoshi, H. Yatsuya, C. Murata, K. Wada, R. Otsuka, N. Nagasawa, M. Ishikawa, K. Sugiura, K. Matsushita, Y. Hori, T. Kondo, and H. Toyoshima. 2005. Long-term body weight fluctuation is associated with metabolic syndrome independent of current body mass index among Japanese men. Circ. J. 69:13-18. 